\title{
Insect Management for Celery and Parsley 1
}

\section{S. E. Webb²}

Celery and parsley (and carrots, treated in another chapter) are related crops in the family Apiaceae (Umbelliferae). Both fall in EPA Crop Group 4, Leafy vegetables. To a large degree they share insect pests and are thus treated together here. Most of the information presented refers only to celery, but pest biology and management options can, in most cases, be applied to parsley. Other related leafy vegetables, for which we do not have specific pesticide tables, include Florence fennel (finochio), and chervil. Key insect pests are described below with additional management options. Pesticides registered for use on celery and parsley are listed in two separate tables at the end of this chapter. Many other insects may occasionally attack these crops but seldom cause economic damage.

\section{American Serpentine Leafminer (Liriomyza trifolii)}

\section{Description}

The adult (Figure 1) is a tiny fly, less than 0.1 inches long, with yellow legs and transparent wings. The head is yellow with red eyes. The rest of the body is mostly gray and black. Eggs are tiny, and oval in shape. They are clear at first and then become creamy white. Eggs hatch into small maggots that feed inside the leaf.

\section{Biology}

The serpentine leafminer has historically been one of the most serious pests of celery in Florida. It also attacks parsley. Its host range is very broad, including many vegetable and floral crops and weeds.

Adult leafminers feed at flowers. In addition, adult females puncture leaves with their ovipositors (egg-laying organs) and feed on the plant juices that accumulate at the feeding puncture. Males, which only live a few days, cannot puncture the leaf, so they

1. This document is ENY-463, one of a series of the Entomology \& Nematology Department, Florida Cooperative Extension Service, Institute of Food and Agricultural Sciences, University of Florida. Published: July 2002. Revised: August 2005. For more publications related to horticulture/agriculture, please visit the EDIS Website at http://edis.ifas.ufl.edu/.

2. S. E. Webb, associate professor, Entomology and Nematology Department, Cooperative Extension Service, Institute of Food and Agricultural Sciences, University of Florida, Gainesville, 32611-0640.

The use of trade names in this publication is solely for the purpose of providing specific information. UF/IFAS does not guarantee or warranty the products named, and references to them in this publication does not signify our approval to the exclusion of other products of suitable composition. All chemicals should be used in accordance with directions on the manufacturer's label. Use pesticides safely. Read and follow directions on the manufacturer's label.

The Institute of Food and Agricultural Sciences (IFAS) is an Equal Opportunity Institution authorized to provide research, educational information and other services only to individuals and institutions that function with non-discrimination with respect to race, creed, color, religion, age, disability, sex, sexual orientation, marital status, national origin, political opinions or affiliations. U.S. Department of Agriculture, Cooperative Extension Service, University of Florida, IFAS, Florida A. \& M. University Cooperative Extension Program, and Boards of County Commissioners Cooperating. Larry Arrington, Dean 


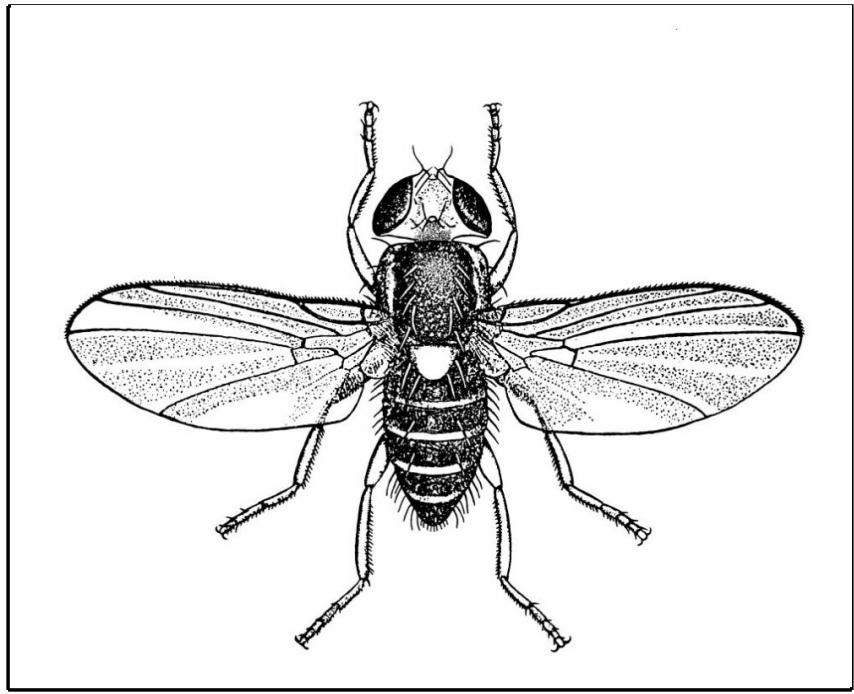

Figure 1. American serpentine leafminer adult (actual size less than 0.1 inches long).

feed after females have left. The female inserts an egg between the upper and lower epidermis (leaf surface), and the larva feeds within the leaf. As the larva feeds, it moves throughout the leaf from within, creating a mine in an irregular line (serpentine mine). The mine increases in diameter as the larva grows and consumes greater amounts of leaf tissue. When fully grown, the larva cuts through the upper leaf surface and leaves the leaf to pupate, falling between the petioles or onto the soil. The larva usually exits the leaf during the morning hours and becomes a pupa by mid-afternoon. After completing the pupal stage, the leafminer emerges from the soil or plant debris as an adult. Adult females can produce 200--400 eggs in their lifetime on celery.

Although leafminers are more abundant during the middle and late part of the season, they can be a problem at any time. The time required for the leafminer to complete its development on celery in the laboratory has been shown to vary from 14 days at $95^{\circ} \mathrm{F}$ to 64 days at $59^{\circ} \mathrm{F}$. Survival of pupae is very low at $95^{\circ}$, however, and reduced egg laying occurs at $59^{\circ}$. Optimum temperature for survival and egg production is $86^{\circ} \mathrm{F}$. A complete life cycle is often completed in 21--28 days. Temperatures in southern Florida, where celery is now produced exclusively, allow leafminers to develop throughout most of the year.

\section{Damage}

Leafminer damage on celery can result in early senescence of outer petioles, longer time to maturity, and a reduction in yield, although celery plants in southern Florida have been shown to withstand substantial leafminer damage without a reduction in growth or yield. Of greater concern to celery and parsley growers is the effect of leafminer feeding on cosmetic quality. Celery plants with insect damage on more than 2 petioles receive a lower grade, according to USDA standards. Protecting celery plants from leafminer damage during the last month of the growing season has been shown to be the key to preventing cosmetic damage to celery in southern Florida.

Table 1. Leafminers

\begin{tabular}{|c|c|}
\hline $\begin{array}{c}\text { Management } \\
\text { Option }\end{array}$ & Recommendation \\
\hline $\begin{array}{l}\text { Scouting/ } \\
\text { Thresholds }\end{array}$ & $\begin{array}{l}\text { During the first two months after } \\
\text { transplanting, leafminer } \\
\text { populations below } 60 \text { pupae per } 20 \\
\text { leaflets held for } 7 \text { days are } \\
\text { acceptable. However, during the } \\
\text { final month in the field, leafminer } \\
\text { densities as low as } 3 \text { pupae per } 20 \\
\text { leaflets can result in a significant } \\
\text { loss in quality. }\end{array}$ \\
\hline Notes & $\begin{array}{l}\text { This insect has developed } \\
\text { resistance to most commonly used } \\
\text { insecticides. The effective } \\
\text { insecticides, cyromazine and } \\
\text { abamectin, should be strictly } \\
\text { rotated according to the label to } \\
\text { manage resistance development. } \\
\text { Selective insecticides, such as } \\
\text { SpinTor and Proclaim, which } \\
\text { control armyworm and cabbage } \\
\text { looper, also provides some control } \\
\text { of leafminer populations and are } \\
\text { soft on most beneficial insects. }\end{array}$ \\
\hline $\begin{array}{l}\text { Natural } \\
\text { Enemies }\end{array}$ & $\begin{array}{l}\text { Tiny wasp parasitoids attack the } \\
\text { larvae and are quite effective at } \\
\text { reducing leafminer populations } \\
\text { unless they are eliminated by the } \\
\text { use of broad-spectrum } \\
\text { insecticides. }\end{array}$ \\
\hline
\end{tabular}


Table 1. Leafminers

\begin{tabular}{|c|c|}
\hline $\begin{array}{c}\text { Management } \\
\text { Option }\end{array}$ & Recommendation \\
\hline $\begin{array}{l}\text { Cultural } \\
\text { Controls }\end{array}$ & $\begin{array}{l}\text { Disk fields to destroy and cover } \\
\text { infested crop residues as soon as } \\
\text { possible after harvest to reduce } \\
\text { infestation of neighboring fields by } \\
\text { emerging adults. }\end{array}$ \\
\hline
\end{tabular}

\section{Beet Armyworm [Spodoptera exigua (Hubner)]}

\section{Description and Biology}

The highly mobile adult moth has dark front wings with mottled lighter markings and hind wings thinly covered with whitish scales. Adults feed on nectar and other moisture sources. Each female can lay over 600 eggs, generally in masses of $80-100$ on the undersides of leaves in the lower plant canopy. Egg masses are covered with fuzzy white scales. Larvae (Figure 2) emerge from egg masses in 3 to 4 days. Very young caterpillars, which are pale with dark heads, feed in groups and then disperse as they grow older (third instar). By the third instar, the dull green caterpillars have wavy, light-colored stripes lengthwise down the back and broader stripes on each side. After feeding from one to three weeks, they construct a cocoon from sand and bits of soil and pupate in the soil, emerging as adults about one week later. Beet armyworm is a tropical insect and survives the winter in southern Florida. It can complete many generations a year there. From southern Florida, adults migrate into northern Florida and other parts of the Southeast.

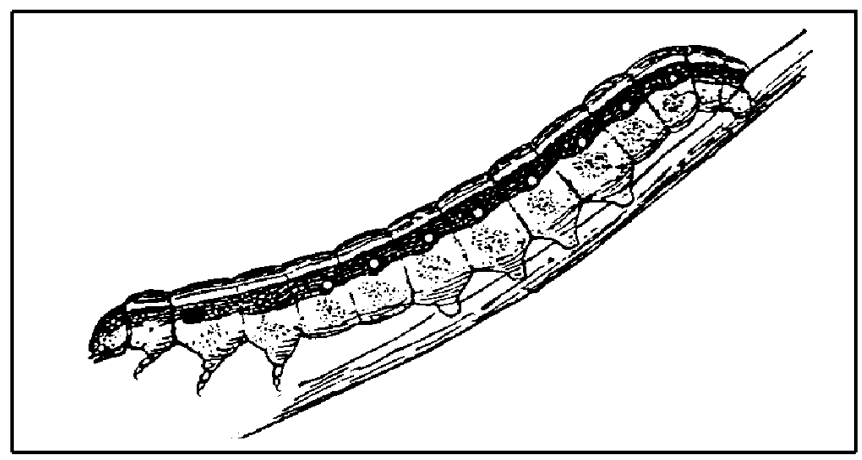

Figure 2. Beet armyworm larva.

\section{Damage}

Armyworms are the principal component of a worm complex that is one of the greatest insect problems of celery in the state. The worm complex, which also includes cutworms and occasionally cabbage loopers, among others, appears each year first in south Florida and then moves northward. The most important of the armyworms on celery and parsley is the beet armyworm, which also feeds on many cultivated and wild plants, including corn, pepper, tomato, potato, onion, pea, sunflower, citrus, soybean and tobacco, as well as plantain and lambsquarters.

Beet armyworm damages celery by feeding in and on the petioles and depositing fecal material throughout the plant, rendering it unmarketable. Older larvae feed closer to the base of the plant and are hard to reach with insecticides.

Beet armyworm populations in southern Florida are highest from late March through mid-June, with a smaller population rise from mid-August through October. The increase in the late summer and fall is thought to be related to beet armyworm activity on late summer weeds, while the population increase in the spring coincides with the leafy vegetable production season in southern Florida.

Table 2. Beet armyworm.

\begin{tabular}{||l|l||}
\hline \hline $\begin{array}{c}\text { Management } \\
\text { Option }\end{array}$ & \multicolumn{1}{c||}{ Recommendation } \\
\hline $\begin{array}{l}\text { Scouting/ } \\
\text { Thresholds }\end{array}$ & $\begin{array}{l}\text { Fields should be monitored at least } \\
\text { weekly for damage by caterpillars } \\
\text { feeding on leaves. Pheromone } \\
\text { traps can be used to monitor } \\
\text { occurrence of moths. Young plants } \\
\text { are more susceptible to damage. } \\
\text { Look for egg masses on the leaves. } \\
\text { Look toward the base of leaves for } \\
\text { damage and under outer leaves } \\
\text { near the soil surface for larvae that } \\
\text { may hide during the day away from } \\
\text { their feeding site. Best time to treat } \\
\text { for this pest is in early morning or } \\
\text { early evening. }\end{array}$ \\
\hline \hline
\end{tabular}


Table 2. Beet armyworm.

\begin{tabular}{|c|c|}
\hline $\begin{array}{c}\text { Management } \\
\text { Option }\end{array}$ & Recommendation \\
\hline Notes & $\begin{array}{l}\text { Insecticides are most effective } \\
\text { against the younger instars with } \\
\text { higher rates and more frequent } \\
\text { applications needed to try to control } \\
\text { later instars. Coverage and } \\
\text { penetration are important in } \\
\text { treating for all of the moth species. } \\
\text { Use of surfactants to increase } \\
\text { surface coverage increases } \\
\text { insecticidal control. Some Bacillus } \\
\text { thuringiensis (Bt) products are } \\
\text { effective against younger larvae } \\
\text { and will help preserve natural } \\
\text { enemies. Some of the newer } \\
\text { products aimed mostly at caterpillar } \\
\text { pests are also less harmful to } \\
\text { beneficial insects. }\end{array}$ \\
\hline $\begin{array}{l}\text { Natural } \\
\text { Enemies }\end{array}$ & $\begin{array}{l}\text { Insect predators and parasitoids, } \\
\text { as well as pathogens aid in control, } \\
\text { but generally do not exert enough } \\
\text { pressure to prevent yield loss. }\end{array}$ \\
\hline $\begin{array}{l}\text { Cultural } \\
\text { Controls }\end{array}$ & $\begin{array}{l}\text { Field disking and destruction of } \\
\text { crop residues are important for } \\
\text { control of all caterpillar pests to } \\
\text { reduce their migration into nearby } \\
\text { crops. Beet armyworms develop } \\
\text { well on several weeds in the } \\
\text { Amaranth (pigweed) group, so } \\
\text { weed control on ditch banks } \\
\text { surrounding fields can help reduce } \\
\text { populations before they invade } \\
\text { fields. }\end{array}$ \\
\hline
\end{tabular}

\section{Granulate Cutworm, (Feltia subterranea) and Black Cutworm (Agrotis ipsilon)}

\section{Description}

Granulate cutworm moths (Figure 3) have a wingspan of 1.2 to 1.7 inches. The front wings are often yellowish-brown and have distinct bean-shaped and round spots in the center. The hind wings are mostly white. Eggs are hemispherical and ridged. They are initially white and darken with age. Larvae (Figure 4) are grayish to reddish-brown. Each abdominal segment has a dull yellowish oblique mark. A weak gray line occurs along the length of the body with spots of white or yellow.

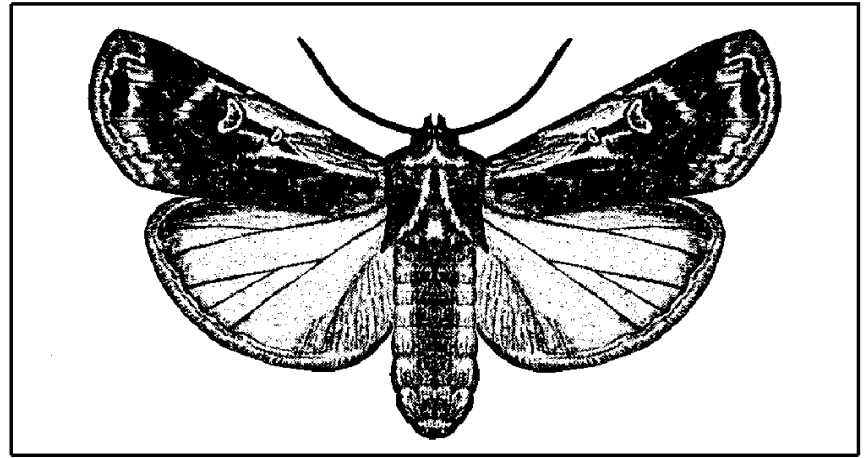

Figure 3. Granulate cutworm moth.

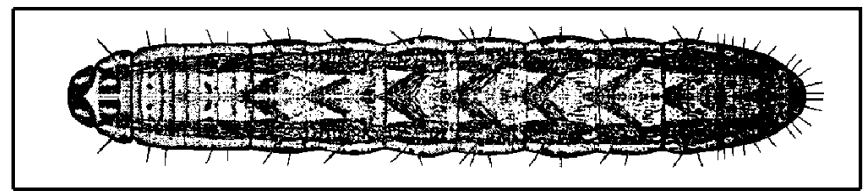

Figure 4. Granulate cutworm larva.

Black cutworm moths (Figure 5) are larger, with a wingspan of 1.5 to slightly over 2 inches. The forewings are dark brown with a lighter band near the end of each wing. The hind wings are whitish to gray. The ribbed eggs are first white, and then turn brown and are usually deposited in clusters. The larvae (Figure 6) are stout, gray caterpillars with a greasy appearance. Black cutworm larvae have numerous dark, coarse granules over most of their bodies.

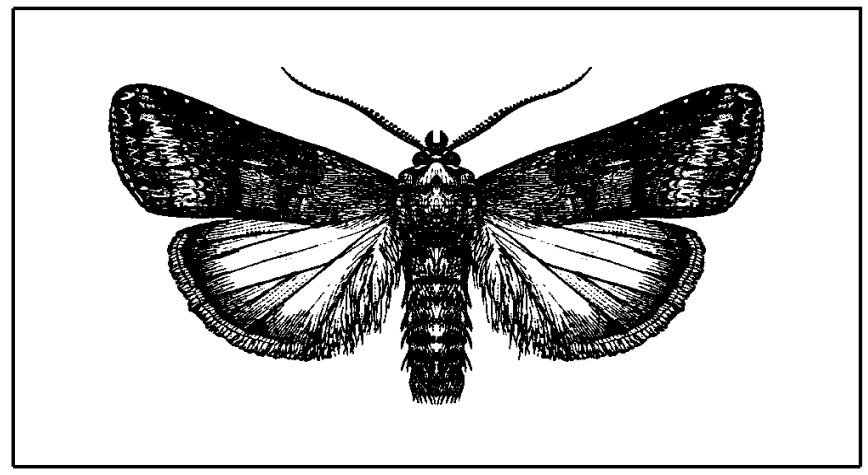

Figure 5. Black cutworm moths.

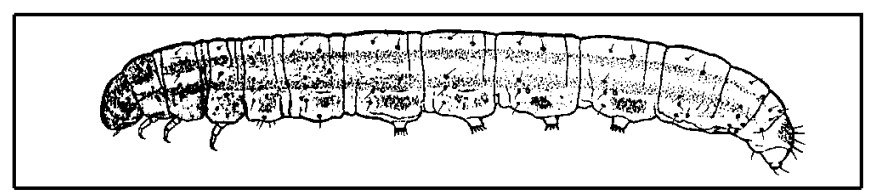

Figure 6. Black cutworm larva.

\section{Biology}

Although the black cutworm is one of the most destructive of the cutworms and attacks a wide range of plants, granulate cutworm is a greater problem on celery. Although cutworm larvae can migrate into a 
field from adjacent areas, most migration occurs by adults flying into the field.

Cutworm moths feed on nectar and other moisture sources. Moths begin depositing eggs on field debris, stubble or leaves near the soil surface 7 to 10 days after emergence. Black cutworm eggs are deposited singly or in groups of up to 30 , and granulate cutworms eggs are deposited singly or in small clusters. Larvae emerge from eggs in 3 to 6 days. Larvae tend to curl up into a ring when disturbed or handled. They may also bite and release a greenish-brown fluid. Larvae are active at night, feeding on leaves and stems of mostly young plants. During the day, they take refuge in the soil at the base of the plants. Larvae complete development in 20 to 40 days. Larvae pupate within a chamber in the soil. Adults emerge in 10 to 20 days. Generation time for cutworms is 35 to 70 days, depending on temperature.

\section{Damage}

Cutworms are another part of the worm complex that attacks celery every year in Florida. Although the black cutworm may be present, granulate cutworm is a greater problem in Florida. These cutworms attack many field and other vegetable crops, including beans, crucifers, cucurbits, corn, cowpea, lettuce, onion, pea, pepper, potato, spinach, sweet potato and tomato. Cutworm larvae become active in the spring. They can cut off plant stems near soil level, and they feed on the leaves, chewing into the developing petioles of celery. Older larvae (4th instar and later) can reach 2 inches in length and can cut plants off at their bases and drag them to their burrow in the soil.
Table 3. Cutworms.

\begin{tabular}{|c|c|}
\hline $\begin{array}{c}\text { Management } \\
\text { Option }\end{array}$ & Recommendation \\
\hline $\begin{array}{l}\text { Scouting/ } \\
\text { Thresholds }\end{array}$ & $\begin{array}{l}\text { Seedling crops should be scouted } \\
\text { as frequently as twice per week to } \\
\text { detect cutworms or their damage, } \\
\text { particularly in areas known for this } \\
\text { pest. Young larvae may be found } \\
\text { grouped together on foliage, but } \\
\text { older larvae will usually be found in } \\
\text { soil or beneath leaf trash during the } \\
\text { day. Look for wilted foliage or } \\
\text { plants with severed stems. Adults } \\
\text { can be monitored with black light } \\
\text { and pheromone traps. }\end{array}$ \\
\hline Notes & $\begin{array}{l}\text { Most of the insecticides available } \\
\text { are foliar sprays. Carbaryl is } \\
\text { available as a bait for both celery } \\
\text { and parsley. }\end{array}$ \\
\hline $\begin{array}{l}\text { Natural } \\
\text { Enemies }\end{array}$ & $\begin{array}{l}\text { Natural enemies such as parasitic } \\
\text { wasps, flies and predacious ground } \\
\text { beetles can exert tremendous } \\
\text { control pressure that may approach } \\
80 \% \text {. However, seedlings emerging } \\
\text { in fields without resident natural } \\
\text { enemy populations can experience } \\
\text { significant stand loss from first } \\
\text { generation cutworms. Larvae are } \\
\text { also targets for attack by } \\
\text { pathogenic fungi and viruses. }\end{array}$ \\
\hline $\begin{array}{l}\text { Cultural } \\
\text { Controls }\end{array}$ & $\begin{array}{l}\text { Weedy fields quickly rotated to } \\
\text { leafy vegetables have higher } \\
\text { potential for stand loss due to } \\
\text { surviving older larvae cutting off the } \\
\text { emerging plants. Therefore, } \\
\text { prepare fallowed fields for } \\
\text { production as soon as possible to } \\
\text { allow time for surviving larvae to } \\
\text { complete development before } \\
\text { planting. }\end{array}$ \\
\hline
\end{tabular}

\section{Description}

Cabbage loopers feed on a variety of crops. The adults (Figure 7) are night-flying moths with brown, mottled fore wings marked in the center with a small, silver figure eight. Their eggs are small, ridged, round, and greenish-white. The eggs hatch into larvae (Figure 8) that are green with white stripes running the length of their bodies. The caterpillar has three 
pairs of slender legs near its head and then three pairs of thick prolegs near the end of its body. It moves in a characteristic looping motion, alternately stretching forward and arching its back as it brings the back prolegs close to its front legs. The caterpillar is about 1.25 inches long when fully grown.

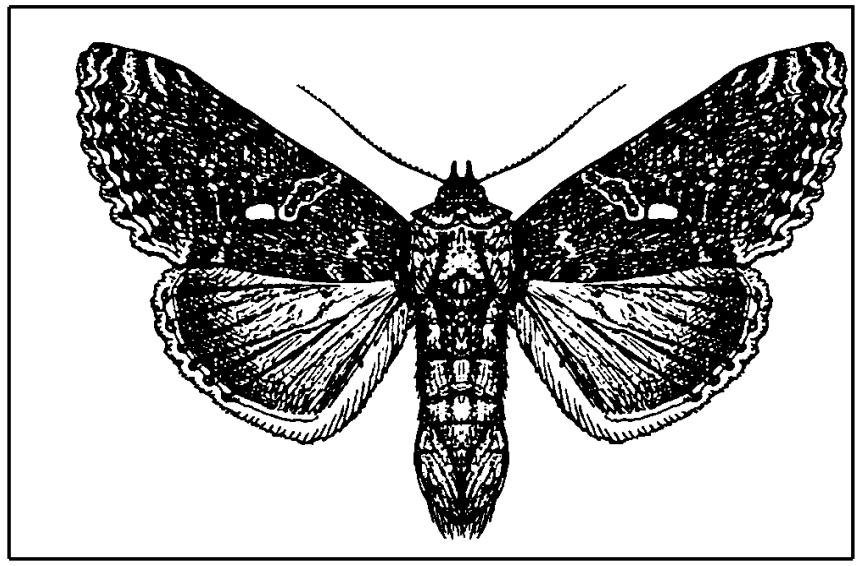

Figure 7. Cabbage looper adult male.

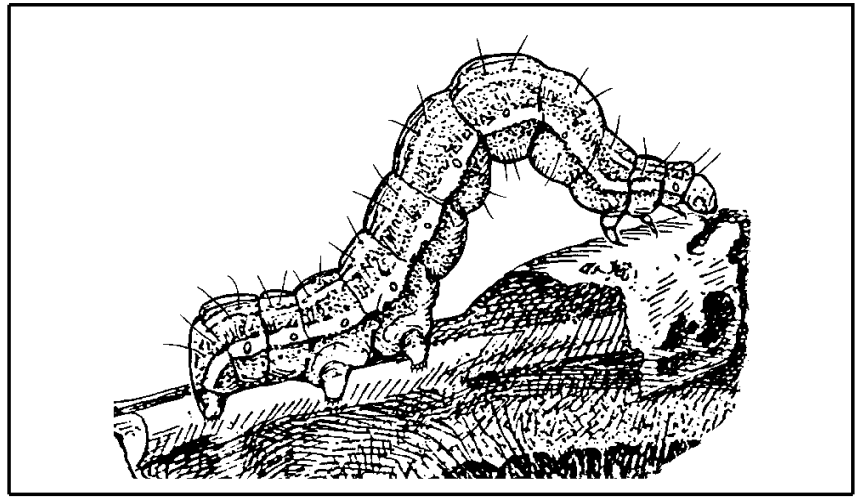

Figure 8. Cabbage looper larva.

\section{Biology}

Eggs are deposited singly or in small clusters on either leaf surface, although more are found on the lower leaf surface. Each female moth can produce 300 to 600 eggs during the approximately 10 to 12 days it is alive. Two to four weeks after hatching, the mature larva spins a thin cocoon on the lower leaf surface, or in plant debris or soil. The pupal stage lasts approximately two weeks. Total time required for development from egg to adult can be as little as 18 days at $21^{\circ} \mathrm{C}\left(69.8^{\circ} \mathrm{F}\right)$ and 25 days at $32^{\circ} \mathrm{C}$ $\left(89.6^{\circ} \mathrm{F}\right)$.

Populations tend to be highest during the late spring and summer months, and in some years in the late fall. Cabbage looper does not enter diapause and cannot survive prolonged cold weather. The insect remains active and reproduces throughout the winter months only in the southern part of Florida (south of Orlando). In central Florida, cabbage looper populations peak during early fall and again during late spring.

\section{Damage}

The cabbage looper occasionally forms part of the worm complex on celery in Florida. It has a broad host range, including cabbage and related crucifers, lettuce, celery, parsley, tomato, potato, spinach, soybean and cotton. In southern Florida, pheromone trapping data shows adult populations to be highest during the late spring and summer months, and in some years, in the late fall.

Damage by cabbage looper larvae is similar to that caused by beet armyworm, but is not as severe. Older larvae are harder to control.

Table 4. Cabbage looper.

\begin{tabular}{||l|l||}
\hline \multicolumn{1}{|c||}{$\begin{array}{c}\text { Management } \\
\text { Option }\end{array}$} & \multicolumn{1}{|c||}{ Recommendation } \\
\hline $\begin{array}{l}\text { Scouting/ } \\
\text { Thresholds }\end{array}$ & Fields should be scouted weekly \\
\hline Notes & $\begin{array}{l}\text { Relying on Bts as the main } \\
\text { insecticide and using some of the } \\
\text { newer pesticides (spinosad, } \\
\text { indoxacarb, tebufenozide) when } \\
\text { needed, will help preserve natural } \\
\text { enemies. }\end{array}$ \\
\hline Natural & $\begin{array}{l}\text { Parasitoid wasps and flies, and } \\
\text { general predators help control } \\
\text { cabbage looper. A nucleopoly- } \\
\text { hedrosis virus also kills loopers. }\end{array}$ \\
\hline $\begin{array}{l}\text { Cultural } \\
\text { Controls }\end{array}$ & $\begin{array}{l}\text { Avoid the warmer months when } \\
\text { pests are most abundant, destroy } \\
\text { crop residues, and control weeds. } \\
\text { Planting a nectar source for } \\
\text { beneficial insects may be } \\
\text { helpful-sweet alyssum has been } \\
\text { tested in cabbage. For high-value, } \\
\text { specialty crops, floating row covers } \\
\text { put in place immediately after } \\
\text { transplanting may eliminate } \\
\text { damage. }\end{array}$ \\
\hline \hline
\end{tabular}




\section{Wireworms or Click Beetles (Elateridae)}

\section{Description}

The adult stage (Figure 9) of this insect is a slender, somewhat flattened, medium to dark brown or gray beetle between $1 / 2$ and $7 / 8$ in. long. Their exoskeletons are smooth or with very short hairs and they have a large tooth-like projection between the rear legs that fits into a groove on the undersurface of the abdomen. These beetles feign death when disturbed and can then right themselves from their backs by quick flexion at the juncture of the thorax and abdomen. The larvae or wireworm (Figure 10) has a narrow, hardened, creamy yellow to orange-brown, tubular body. Characteristic hardened projections on the next to last abdominal segment can be used to identify them to species. They have three pairs of short true legs and no prolegs and can reach 1 $1 / 4$ in. long. Pupae are naked with legs, antennae and wing buds completely visible.

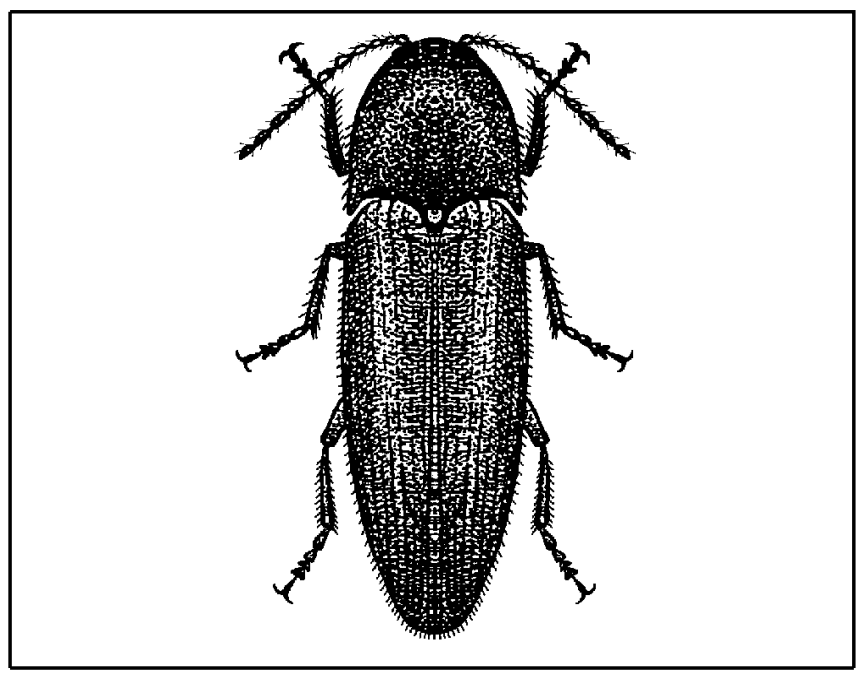

Figure 9. Click beetle (adult).

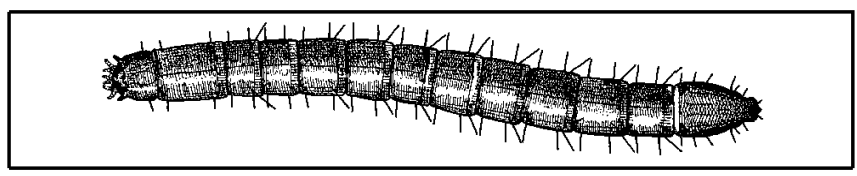

Figure 10. Corn wireworm larva.

\section{Biology}

Depending on species and soil temperature, wireworm larvae can take from 1 to 5 years to develop. Corn wireworm (Melanotus communis), common in Florida, may complete its development in
2 to 3 years in south Florida. Most flight activity occurs in May and June. Females lay eggs in cracks or crevices or burrow into the soil. Larvae tend to move deeper as soil temperatures become hotter and move closer to the soil surface when it is cooler. If temperatures drop further, larvae will again move deeper into the soil. Other wireworms found in Florida (Conoderus spp.) can complete their development in a year or less, resulting in up to three generations per year in south Florida. These species tend to stay close to the soil surface.

\section{Damage}

Larvae attack seeds, roots and crowns of plants below the soil surface. They chew into the base of plants and then hollow out the stem, eliminating the growing points. Young plants first exhibit severe wilting and desiccation of the youngest leaves. Plant death and stand loss quickly follow after plants begin to wilt.

Table 5. Wireworms.

\begin{tabular}{|c|c|}
\hline $\begin{array}{c}\text { Management } \\
\text { Option }\end{array}$ & Recommendation \\
\hline $\begin{array}{l}\text { Scouting/ } \\
\text { Thresholds }\end{array}$ & $\begin{array}{l}\text { Soil within an area } 8 \text { inches in } \\
\text { diameter around affected plants } \\
\text { should be excavated in search of } \\
\text { larvae in or near these plants. If } \\
\text { infestation density is in question, } \\
\text { then fields should be sampled for } \\
\text { these pests to determine the best } \\
\text { treatment strategy before crop is } \\
\text { planted. Baits of oat, corn or potato } \\
\text { buried in fields and recovered in } 2 \\
\text { to } 3 \text { wk work well to monitor } \\
\text { wireworms. Average counts }>2 \text { per } \\
\text { bait are enough to recommend } \\
\text { treatment. }\end{array}$ \\
\hline Notes & $\begin{array}{l}\text { Dichloropropene is the only } \\
\text { insecticide (restricted use) labeled } \\
\text { for wireworm control in celery and } \\
\text { parsley and must be applied } \\
\text { preplant. The best strategy is to } \\
\text { sample for wireworms before } \\
\text { planting and avoid fields that have } \\
\text { an infestation. }\end{array}$ \\
\hline $\begin{array}{l}\text { Natural } \\
\text { Enemies }\end{array}$ & $\begin{array}{l}\text { Birds such as cattle egrets that } \\
\text { follow farm equipment through the } \\
\text { field can eat many wireworms } \\
\text { exposed during field disking. }\end{array}$ \\
\hline
\end{tabular}


Table 5. Wireworms.

\begin{tabular}{||l|l||}
\hline \multicolumn{1}{|c|}{$\begin{array}{c}\text { Management } \\
\text { Option }\end{array}$} & \multicolumn{1}{c|}{ Recommendation } \\
\hline Contrural & $\begin{array}{l}\text { Celery planted to weedy fields, or in } \\
\text { rotation from pasture or sugarcane, } \\
\text { is often exposed to very large } \\
\text { wireworm populations. Summer } \\
\text { flooding of fields is an effective } \\
\text { cultural control, providing it is } \\
\text { maintained for at least several } \\
\text { weeks. Water temperature should } \\
\text { be above 82 } \mathrm{F} \text { for maximum } \\
\text { control. Rotation through a cycle of } \\
\text { rice has been shown to eliminate } \\
\text { the need for wireworm treatment in } \\
\text { the subsequent crop. }\end{array}$ \\
\hline \hline
\end{tabular}

\section{Aphids}

Aphids are usually minor pests on celery in Florida, but they may be of concern because of their role as virus vectors. The most important aphids on celery are the green peach aphid (Myzus persicae) and the melon aphid (Aphis gossypii). Green peach aphid is the primary aphid attacking parsley. The green citrus aphid (Aphis spiraecola) may also colonize celery in Florida. An aphid pest newly introduced to Florida, Hyadaphis coriandri, may colonize celery and parsley. Primarily a pest of coriander and other umbelliferous herbs, it has the potential to become a serious pest if it becomes established in crop areas.

\section{Description}

Adults are soft-bodied, pear- or spindle-shaped insects with a posterior pair of tubes (cornicles or siphunculi), which project upward and backward from the upper surface of the abdomen and which are used for excreting a defensive fluid. Aphids have needle-like piercing-sucking mouthparts. Immature aphids or nymphs are smaller but otherwise similar in appearance to wingless adults. Green peach aphid adults (Figure 11) vary from 0.04 to 0.08 inches in length and are light green to yellow to pink and pear-shaped. The tubercles (bumps between antennae) point inward and are a distinguishing characteristic. Winged forms have a black patch on the back of the abdomen.

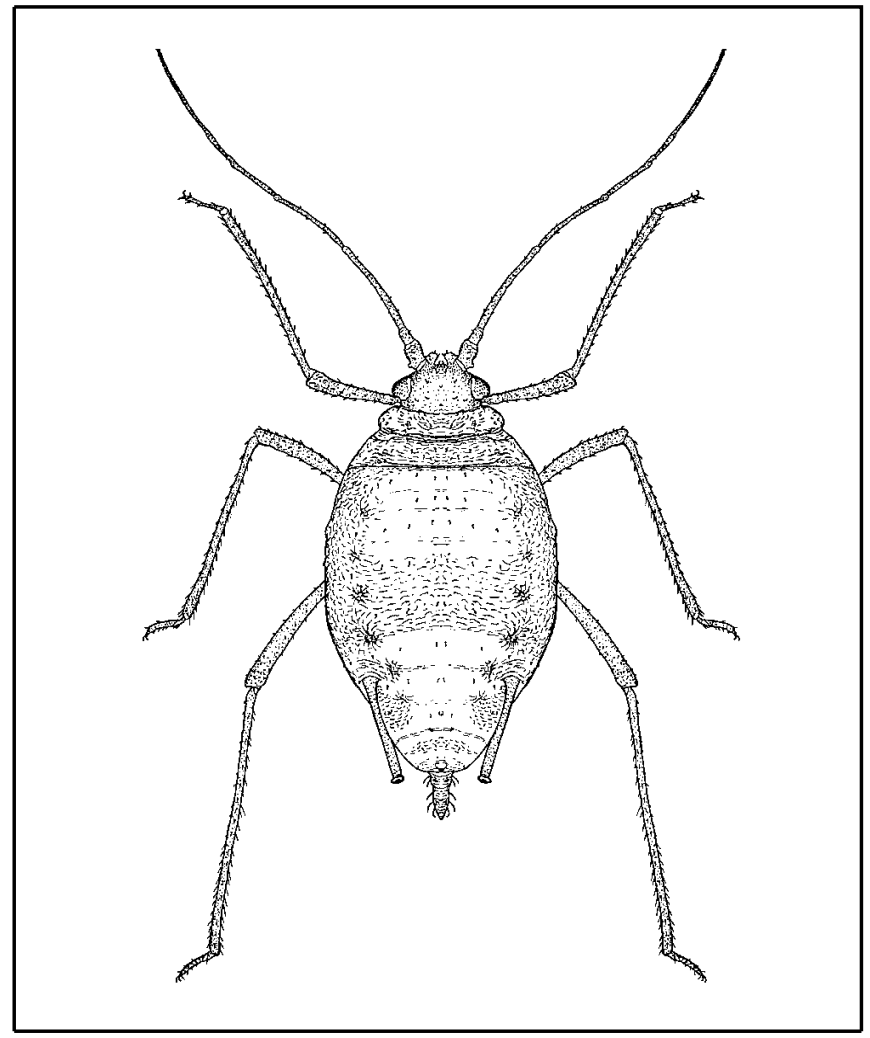

Figure 11. Green peach aphid.

Melon aphids (Figure 12) are almost egg-shaped when viewed from above. The largest ones are not much longer than one-sixteenth of an inch in length. Their color can vary from pale yellow to orange to dark green to almost black. The cornicles are dark and the cauda (a small tail-like structure) is pale or dusky.

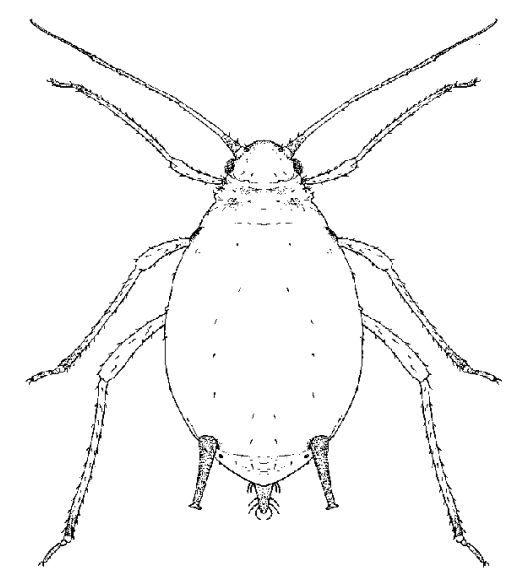

Figure 12. Melon aphid. 


\section{Biology}

Aphids feed by inserting their needle-like mouthparts into plant tissue and sucking up plant juices. In addition to depleting the plant of nutrients, they can inject toxins that produce abnormal plant growth. While feeding, they also excrete large amounts of a sweet, sticky liquid called honeydew that ants are attracted to and feed on. Ants will defend aphids against predators. Sooty mold will grow on heavy deposits of honeydew.

Aphids reproduce rapidly, giving birth to nymphs rather than laying eggs. The newborn nymphs begin feeding immediately. The nymphs pass through several instars before molting into adults in 7 to 10 days. As a result of this rapid reproduction, aphid populations can increase dramatically. When aphids become crowded or if their host plant deteriorates, winged aphids develop and fly to new plants.

\section{Damage}

The green peach aphid (Myzus persicae), in addition to feeding on celery, also colonizes a wide range of plants, including cabbage and related crucifers, parsley, turnip, lettuce, chard, endive, tomato, potato, pepper, beets, spinach, and mustard greens. It is one of the most important aphid virus vectors and can transmit over 100 plant viruses, including those that affect celery in Florida (cucumber mosaic virus and celery mosaic virus). The green peach aphid has developed resistance to a great number of insecticides

The melon aphid (Aphis gossypii) is also a vector of both celery viruses in Florida. It has a broad host range as well and can colonize beans, cowpea, citrus, cucurbits, eggplant, peppers, potato, tomato, spinach, okra, beets, cotton, and many ornamental plants, as well as having many weed hosts. Many overlapping generations occur each year

In addition to depleting plant nutrients by their feeding, and transmitting plant viruses, aphids also contaminate plants. Contamination of fresh market celery with honeydew, cast skins, and aphids, both dead and alive, can lower the value of the crop.
Table 6. Aphids.

\begin{tabular}{|c|c|}
\hline $\begin{array}{c}\text { Management } \\
\text { Option }\end{array}$ & Recommendation \\
\hline $\begin{array}{l}\text { Scouting/ } \\
\text { Thresholds }\end{array}$ & $\begin{array}{l}\text { No thresholds have been } \\
\text { determined. Examine plants } \\
\text { weekly, especially after petioles } \\
\text { start to form. Intermediate age } \\
\text { stalks are most likely to be infested. } \\
\text { Check field edges carefully, } \\
\text { especially if celery or parsley is } \\
\text { being grown next to lettuce. }\end{array}$ \\
\hline Notes & $\begin{array}{l}\text { Chemicals with systemic or } \\
\text { translaminar penetrating activity } \\
\text { are effective for aphid control. } \\
\text { Avoid broad-spectrum pesticides, if } \\
\text { possible, to preserve natural } \\
\text { enemies. }\end{array}$ \\
\hline $\begin{array}{l}\text { Natural } \\
\text { Enemies }\end{array}$ & $\begin{array}{l}\text { Many types of natural enemies may } \\
\text { control these aphids under low } \\
\text { insecticide input situations. } \\
\text { However, these aphids reproduce } \\
\text { quickly and move into protected } \\
\text { areas of the plants, thereby greatly } \\
\text { reducing the potential impact of } \\
\text { their predators and parasitoids in } \\
\text { older stage plants. Pathogens kill } \\
\text { many winged adults before they } \\
\text { begin producing nymphs. }\end{array}$ \\
\hline $\begin{array}{l}\text { Cultural } \\
\text { Controls }\end{array}$ & $\begin{array}{l}\text { Field disking and destruction of } \\
\text { crop residues are important for } \\
\text { control of all caterpillar, aphid and } \\
\text { leafminer pests of leafy vegetables } \\
\text { to reduce their migration into } \\
\text { nearby crops. }\end{array}$ \\
\hline
\end{tabular}

\section{Twospotted Spider Mite (Tetranychus urticae)}

\section{Description and Biology}

Spider mites are nearly microscopic, but stippling on the upper surface of leaves and mites and webbing on the lower surface are good indicators of their presence. Eggs are whitish and spherical. The first instar is called a larva and has only 3 pairs of legs. Later stages are called nymphs and have 4 pairs of legs like the adults. Adults (Figure 13) have numerous long hairs on their legs, but only a few on their bodies. Often, the feeding female is greenish with two dark spots on her back, but color is not very reliable for identification. 


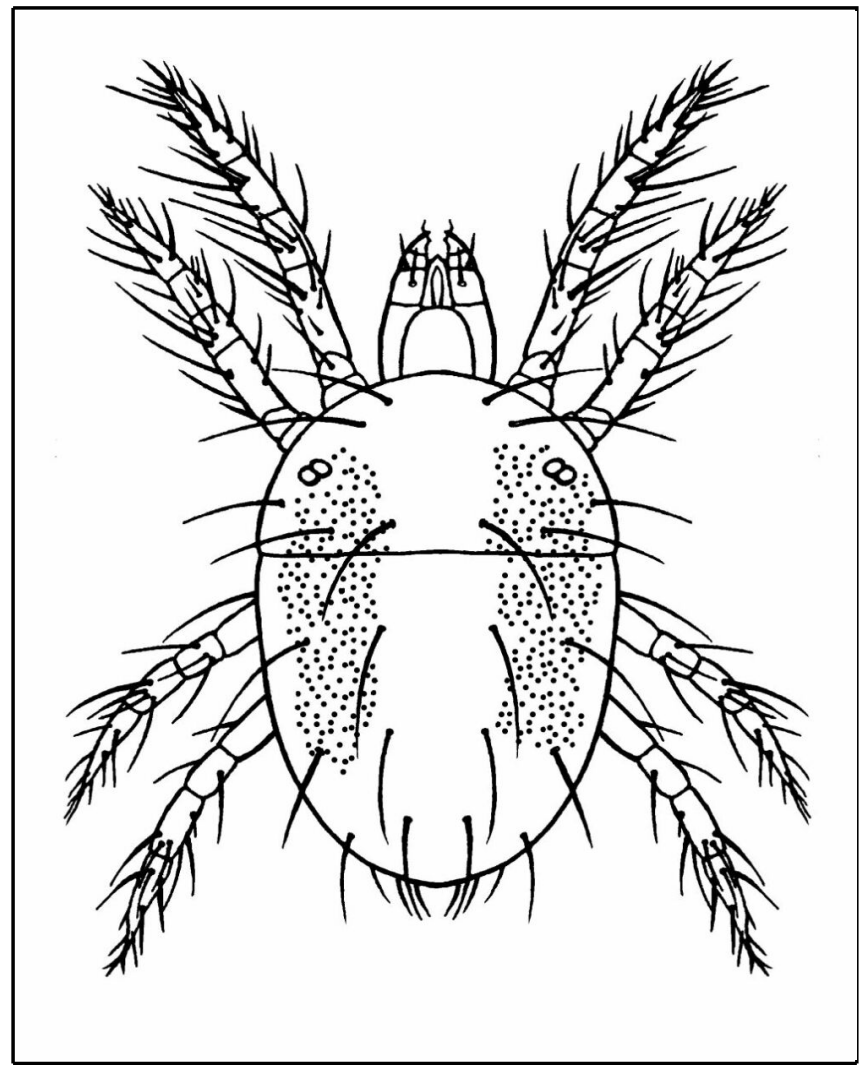

Figure 13. Twospotted spider mite (female).

Hot, dry weather speeds spider mite development, and populations may increase rapidly under optimum conditions. Each female may produce up to 19 eggs per day and a total of up to 100 eggs. The larvae hatch after 6 to 19 days and begin to feed, piercing the leaf surface (epidermis) with their long, slender mouthparts and withdrawing plant sap. Mites experience a resting period after the larval stage, then pass through two nymphal stages, with another resting period after each one. Maturity into adults may take as few as five days or as many as 20 days, depending on the temperature.

\section{Damage}

Twospotted spider mites are a minor and occasional pest of celery in Florida. They are more of a problem later in the season, when their presence on the harvested product is undesirable. Symptoms of spider mite damage begin with a bronzed appearance on leaves and include yellow and reddish-brown blotches on both leaf surfaces. Under severe infestations, paling and dropping of leaves may occur.
Table 7. Twospotted spider mite.

\begin{tabular}{|c|c|}
\hline $\begin{array}{c}\text { Management } \\
\text { Option }\end{array}$ & Recommendation \\
\hline $\begin{array}{l}\text { Scouting/ } \\
\text { Thresholds }\end{array}$ & $\begin{array}{l}\text { Periodically check plants for } \\
\text { symptoms of damage, especially } \\
\text { when weather is warm and dry. No } \\
\text { thresholds have been established } \\
\text { for mites on celery and parsley. }\end{array}$ \\
\hline Notes & $\begin{array}{l}\text { The age structure of the population } \\
\text { should be determined when } \\
\text { considering the use of chemical } \\
\text { controls. When many nymphs are } \\
\text { present, the population is probably } \\
\text { increasing, whereas if many adults } \\
\text { are present, particularly males, it is } \\
\text { probably declining. In addition, if a } \\
\text { miticide is used, a second } \\
\text { application is necessary between } \\
\text { five and seven days after the first to } \\
\text { kill mites that were in the egg stage } \\
\text { at the first application. There are no } \\
\text { effective miticides labeled for use } \\
\text { on parsley. Consider using } \\
\text { predatory mites and pirate bugs, } \\
\text { available commercially. }\end{array}$ \\
\hline $\begin{array}{l}\text { Natural } \\
\text { Enemies }\end{array}$ & $\begin{array}{l}\text { Mites are attacked by many other } \\
\text { insects and mites. Predatory mites } \\
\text { and pirate bugs (Orius spp.) are } \\
\text { particularly important. Some thrips } \\
\text { attack mites. Mites are also } \\
\text { susceptible to fungal disease. }\end{array}$ \\
\hline $\begin{array}{l}\text { Cultural } \\
\text { Controls }\end{array}$ & $\begin{array}{l}\text { Dry, dusty conditions favor spider } \\
\text { mites and water-stressed plants } \\
\text { are more susceptible. Overhead } \\
\text { irrigation may help alleviate mite } \\
\text { problems. Avoid excessive } \\
\text { nitrogen. }\end{array}$ \\
\hline
\end{tabular}




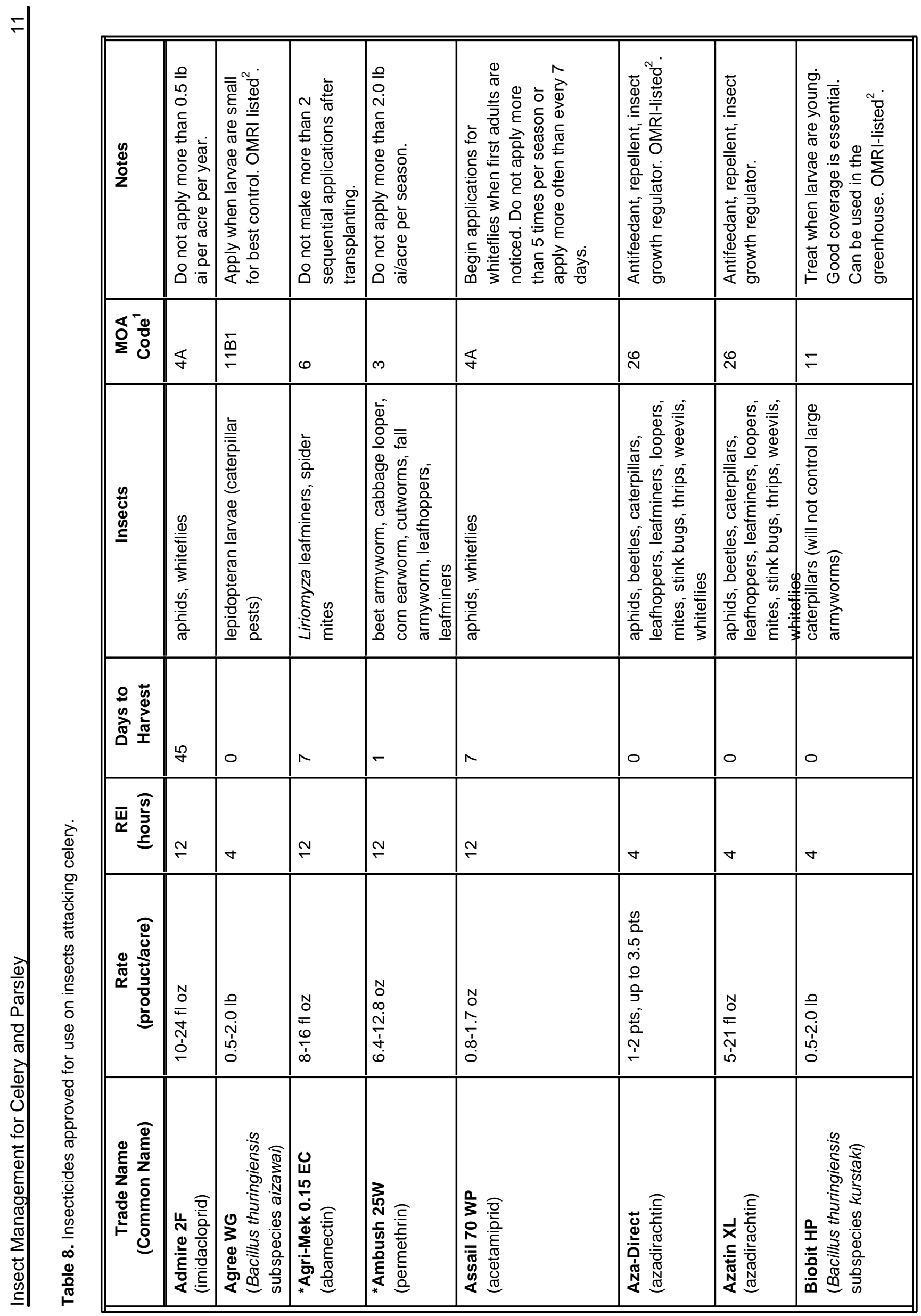




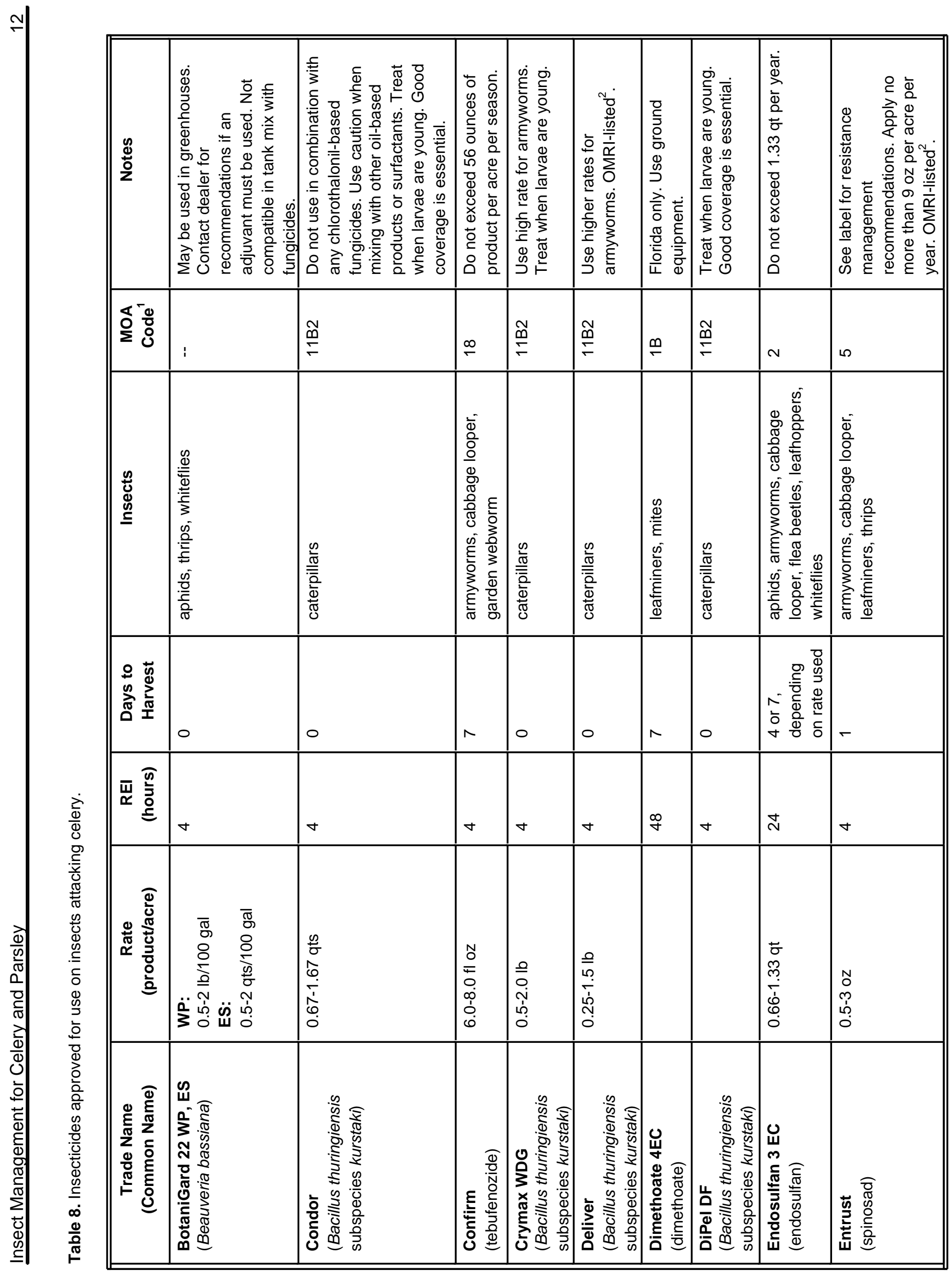




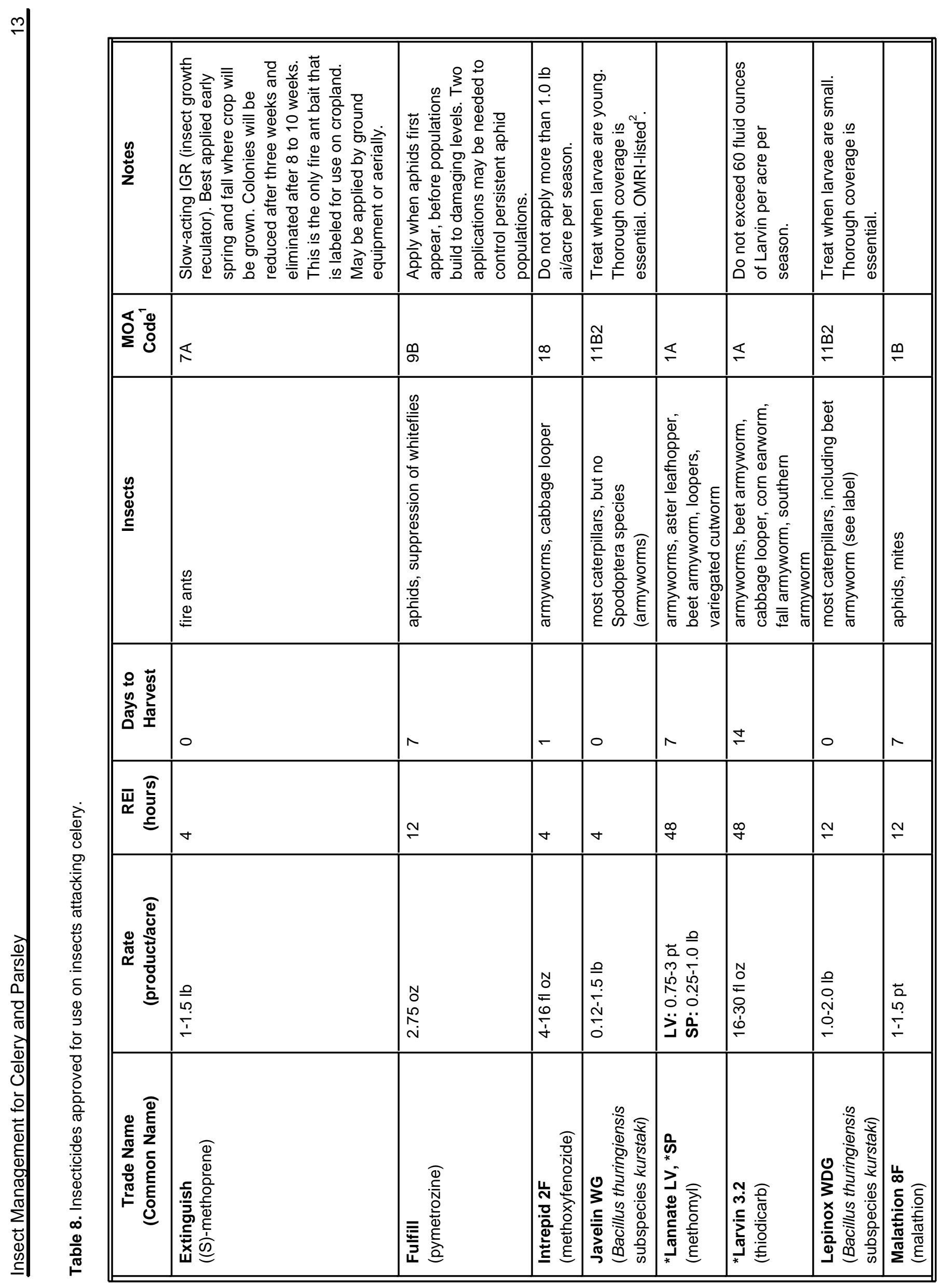




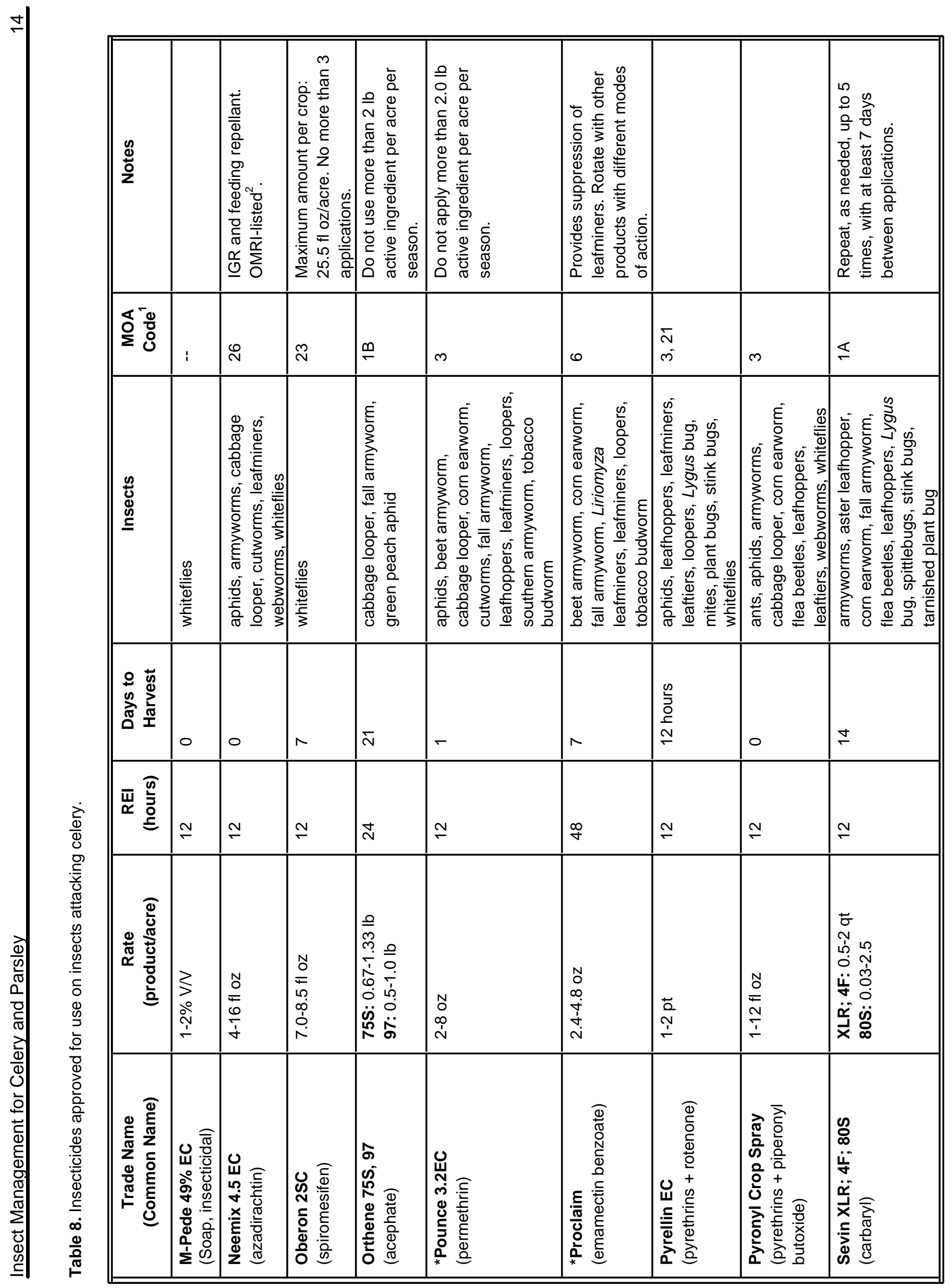




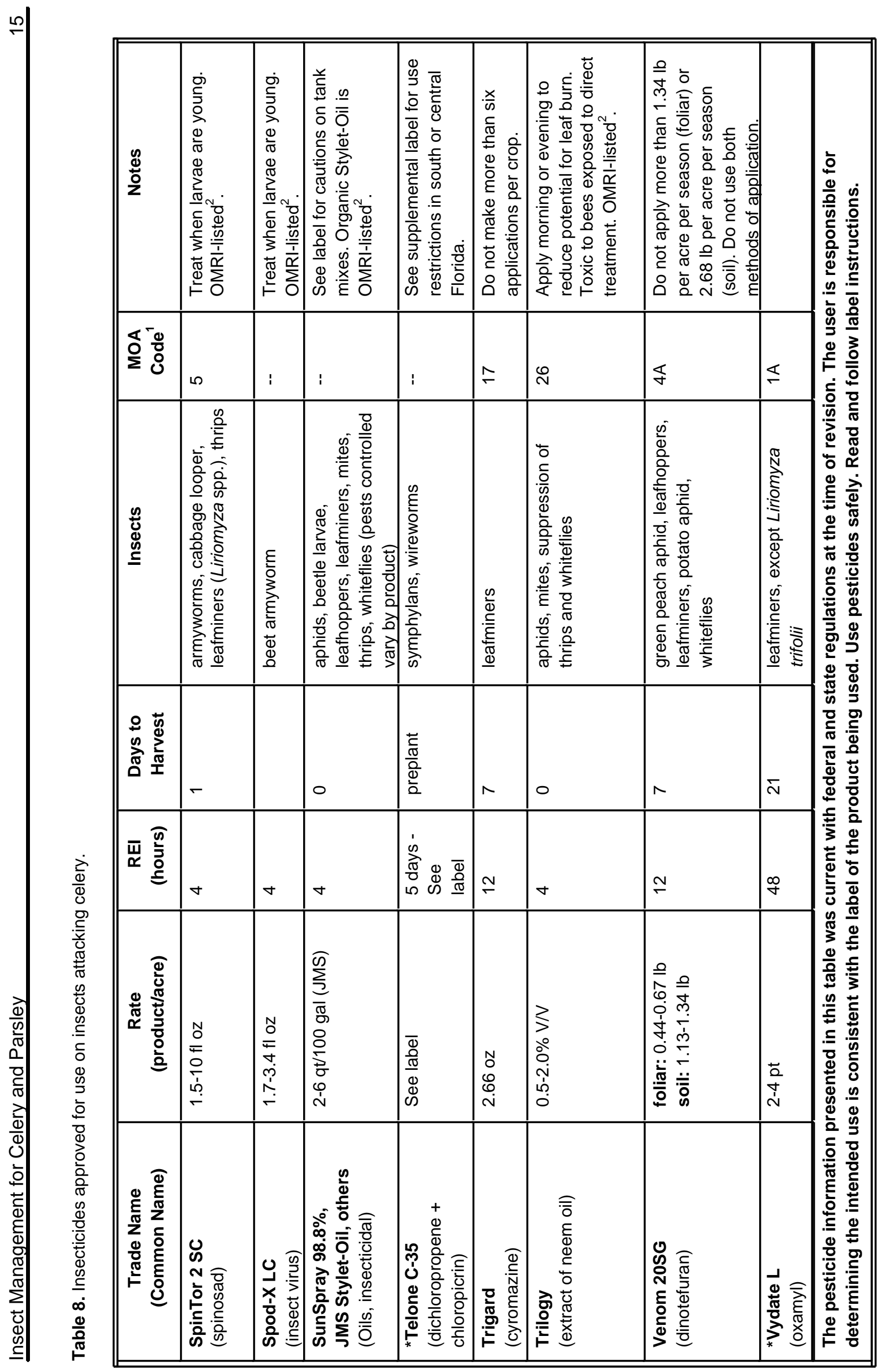




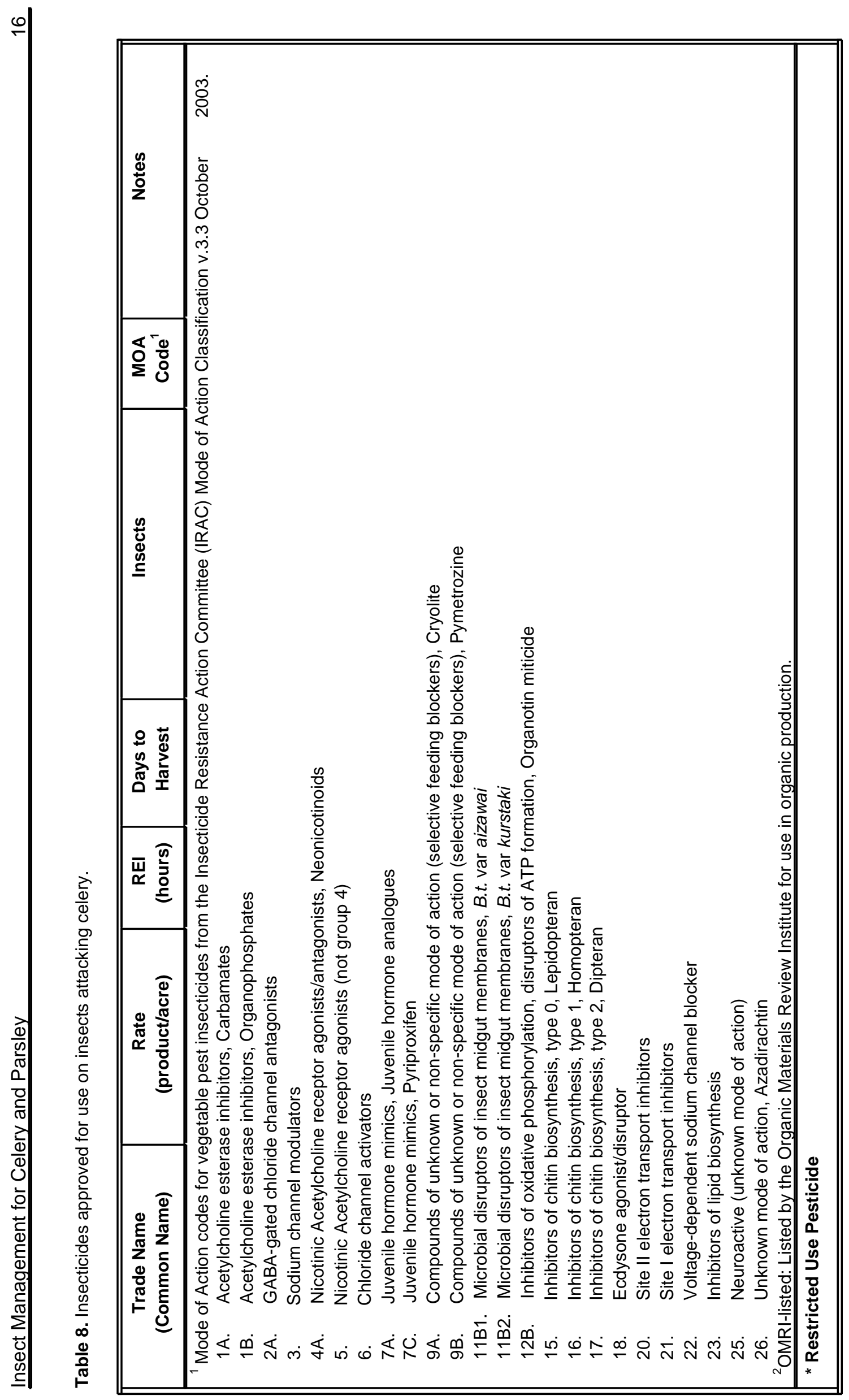




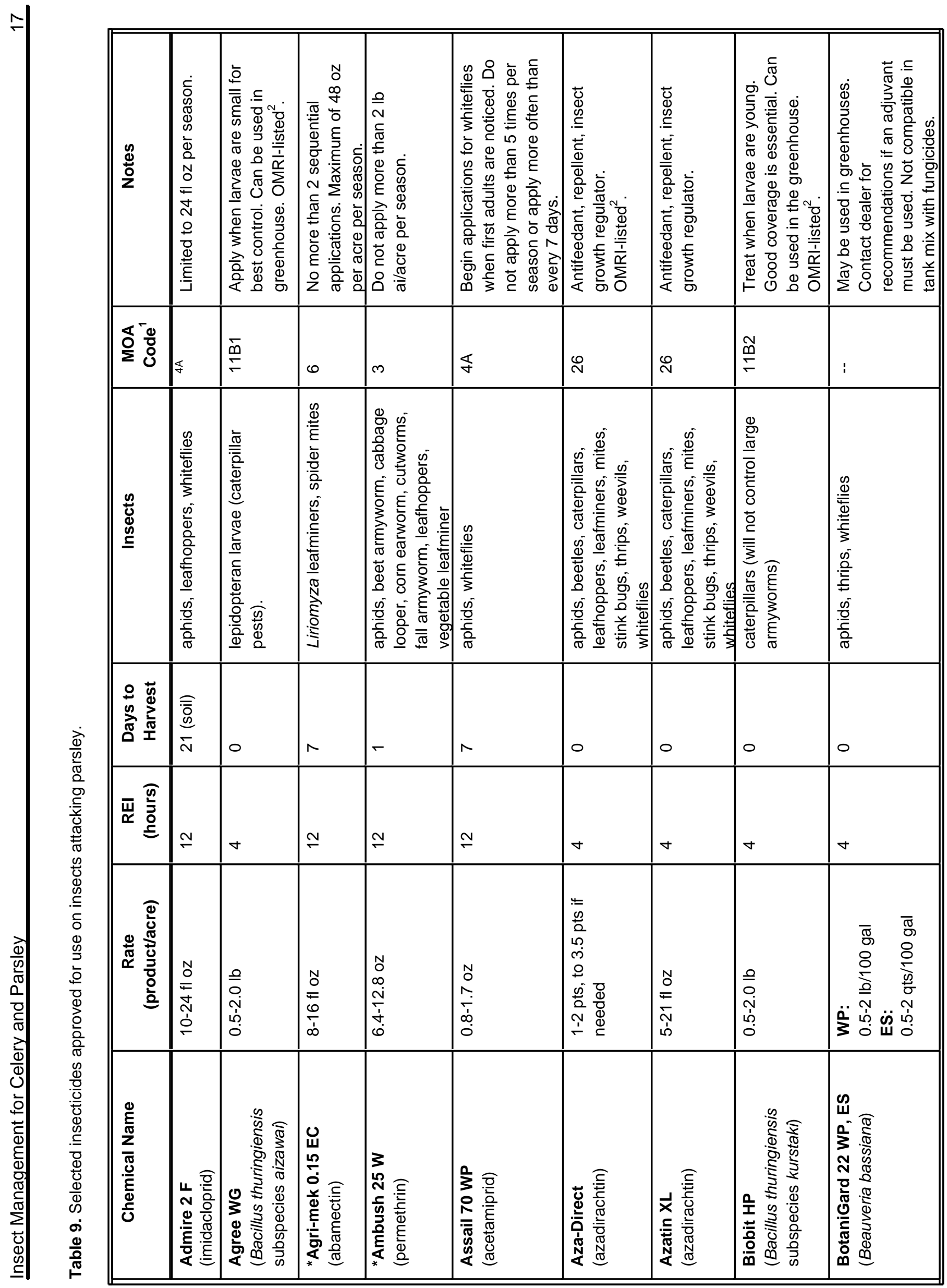




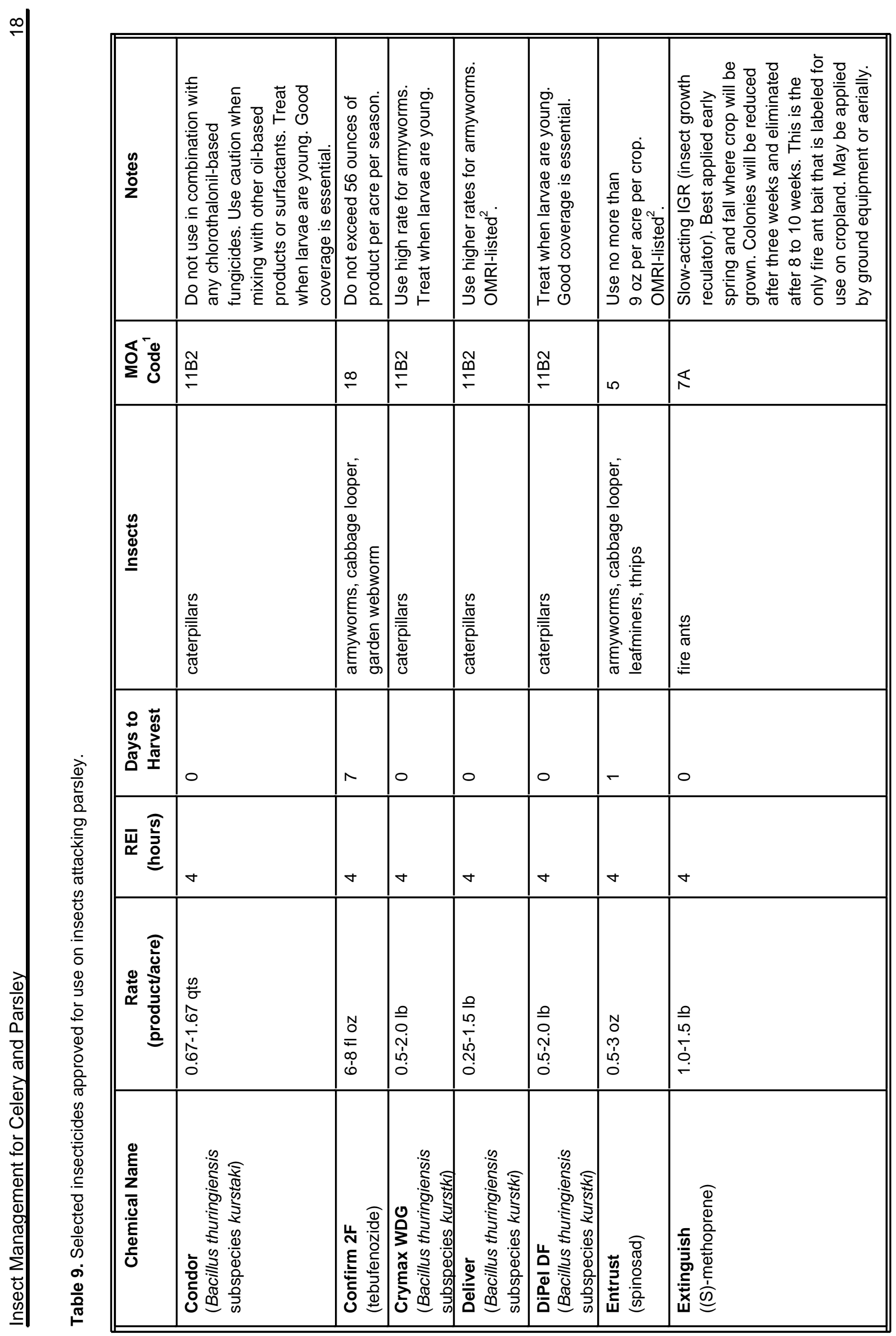




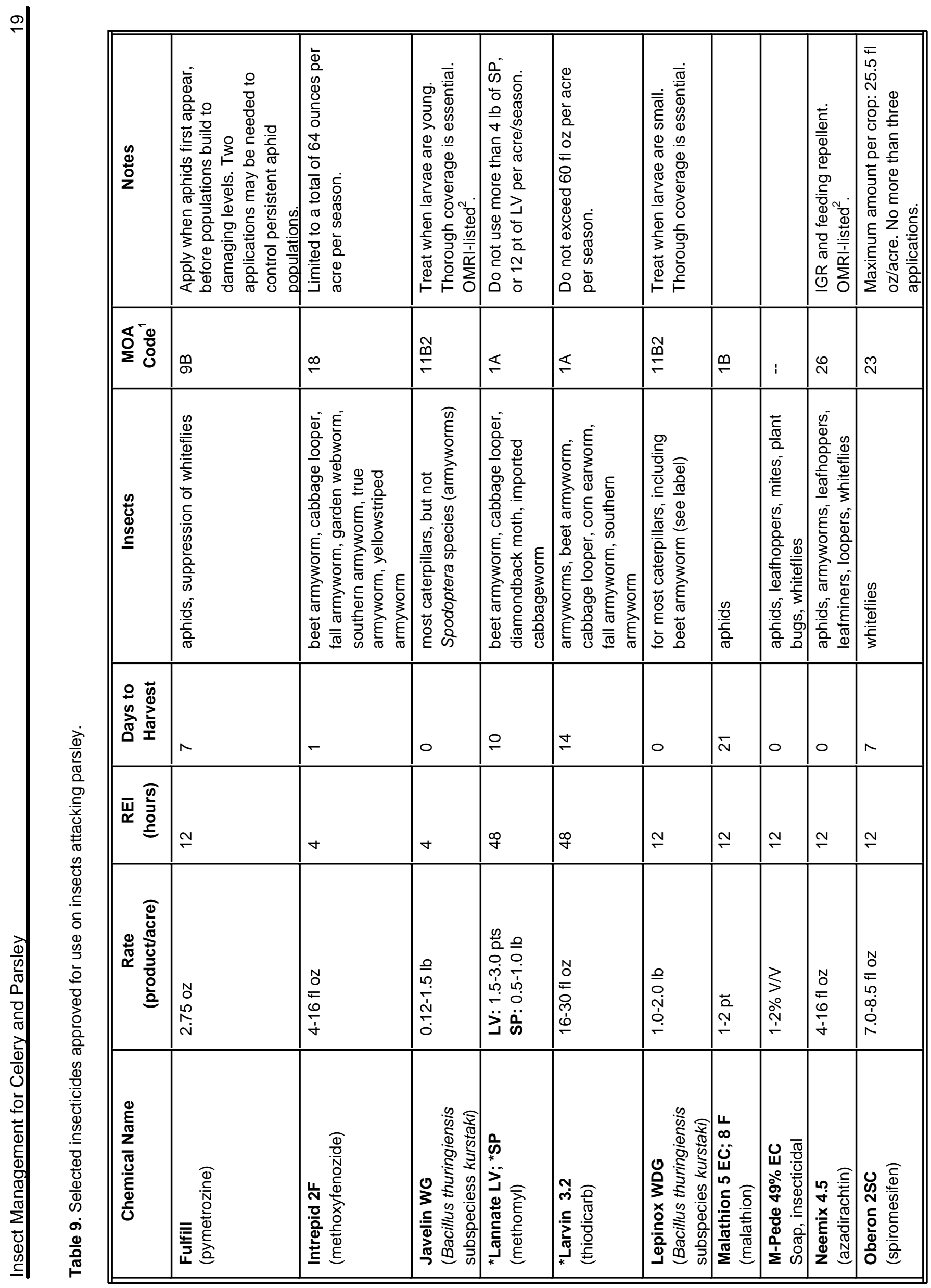




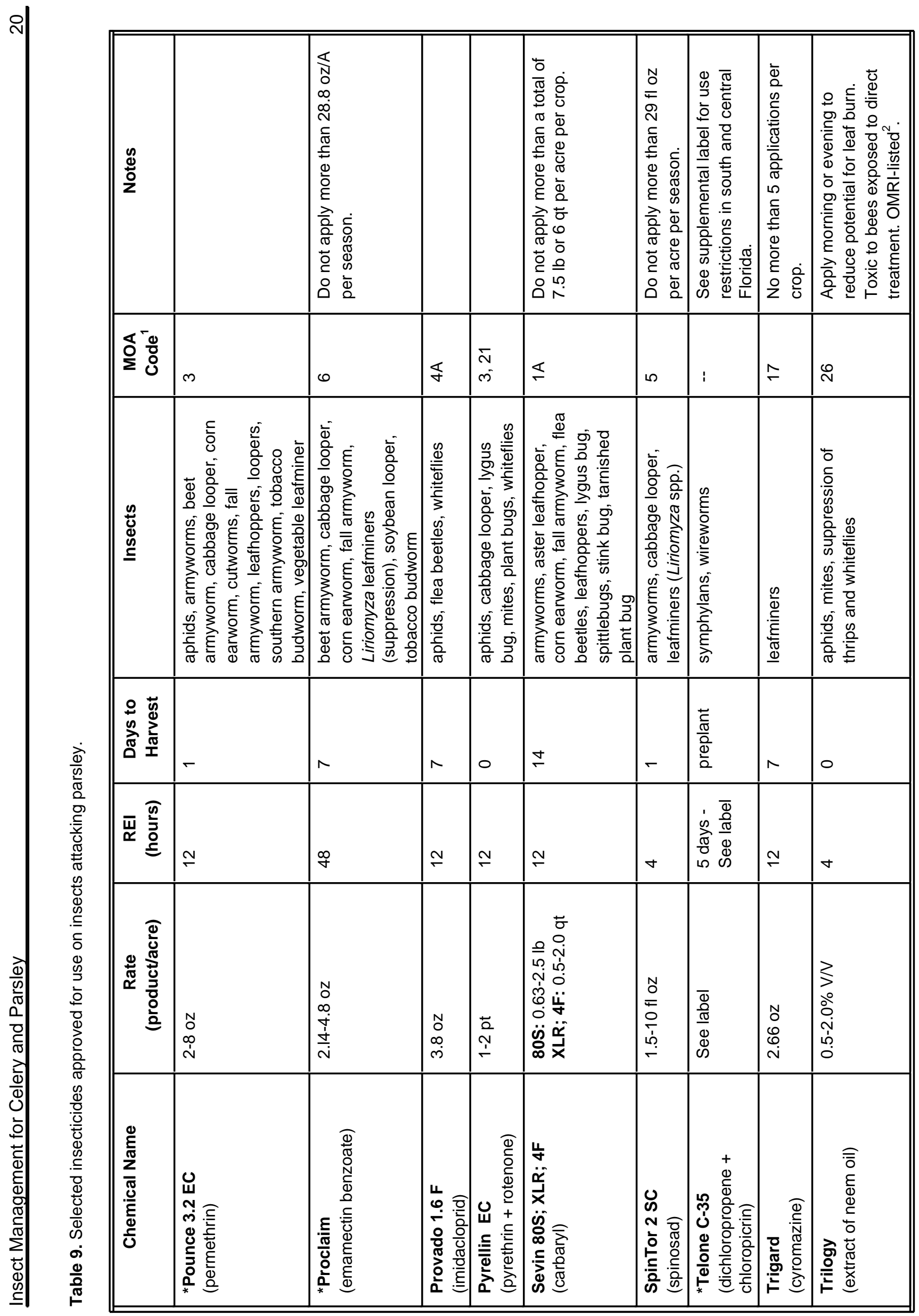




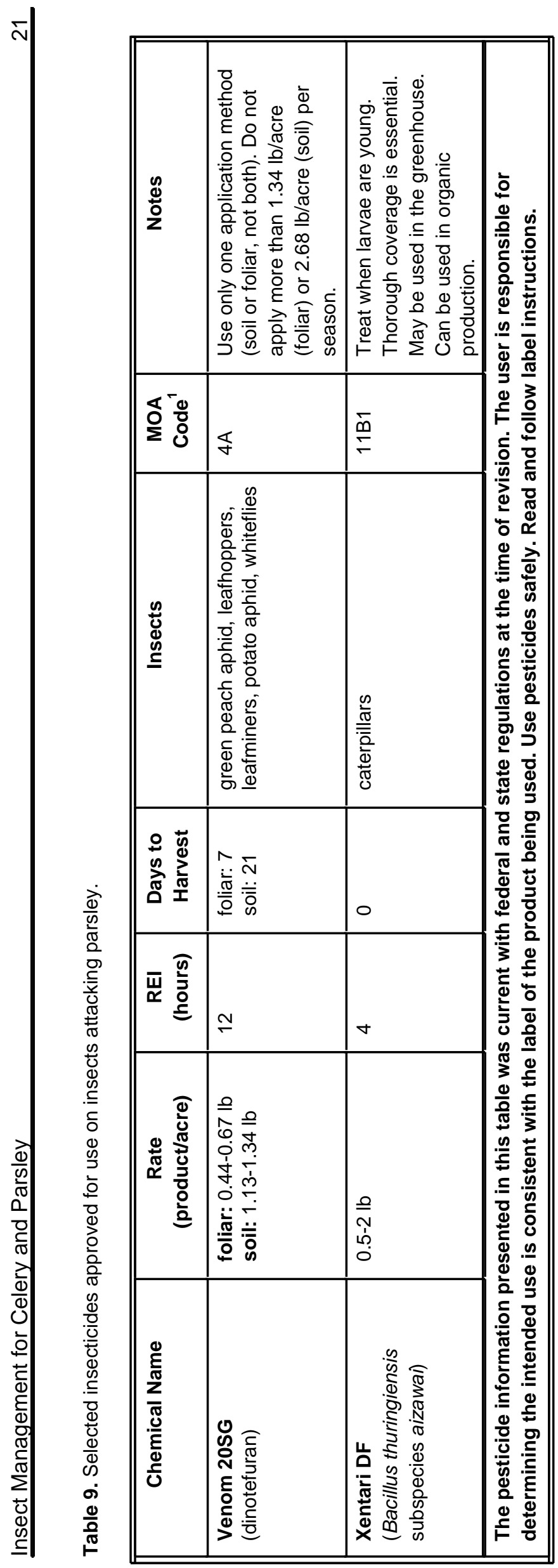




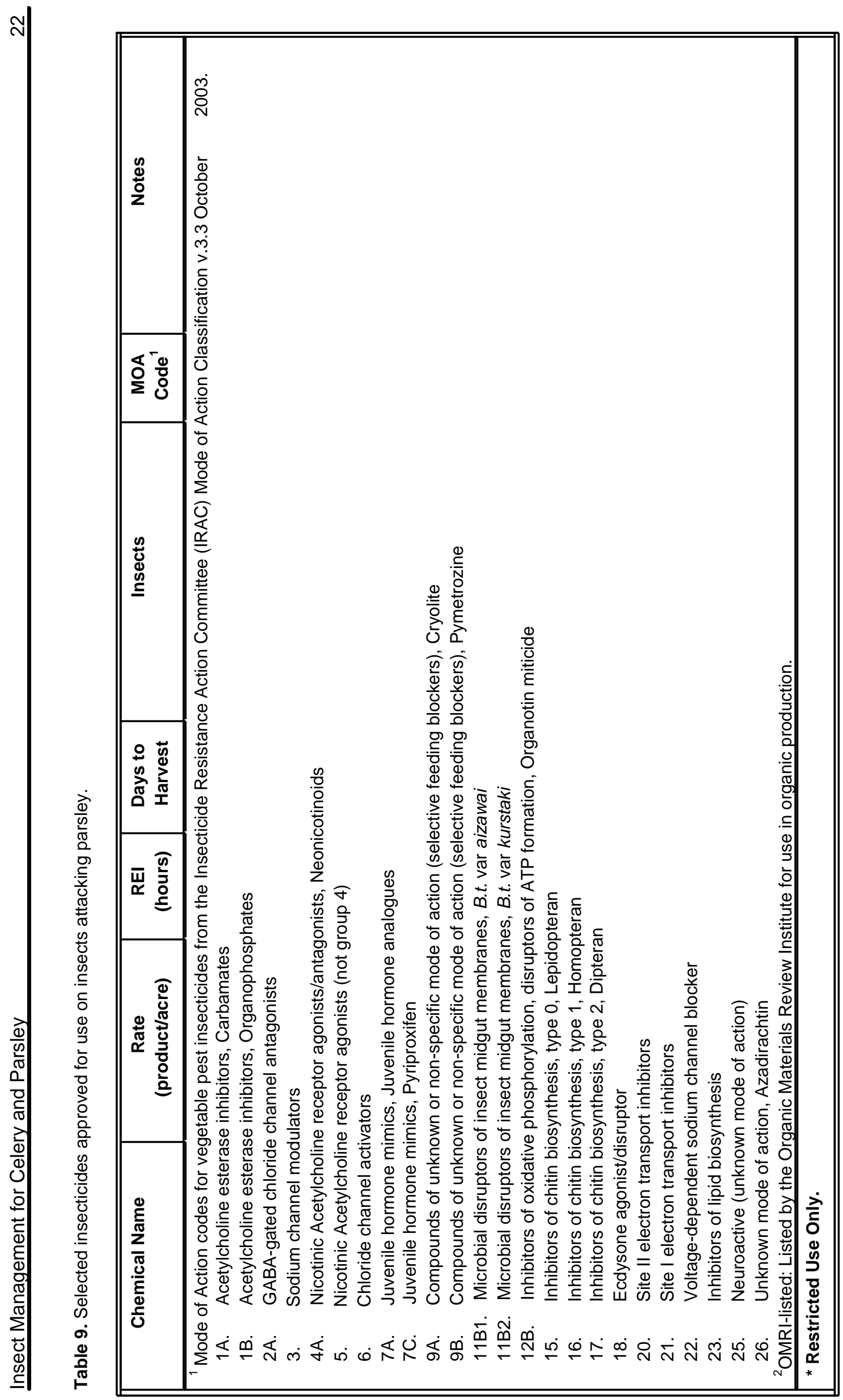

